
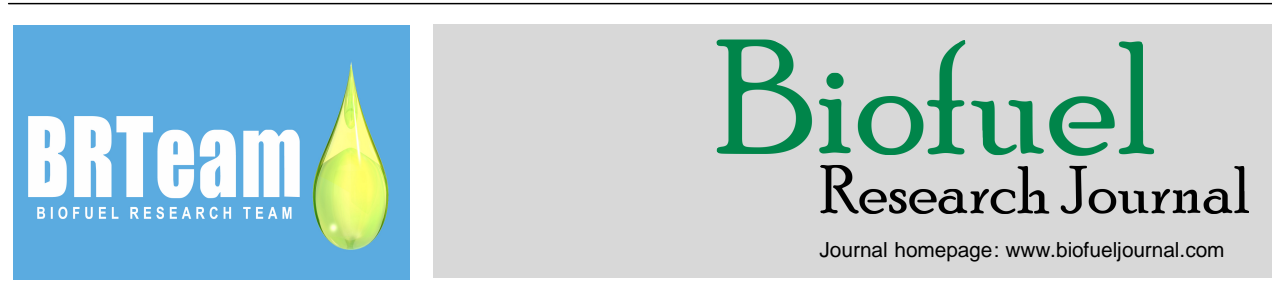

Original Research Paper

\title{
A rapid sampling technique for isolating highly productive lipid-rich algae strains from environmental samples
}

\author{
Suting T. Huang ${ }^{1}$, Jo L. Goh ${ }^{2}$, Hossein Ahmadzadeh ${ }^{3}, *$ Marcia A. Murry ${ }^{1}$ \\ ${ }^{I}$ Department of Biological Sciences, California State Polytechnic University, Pomona, CA. \\ ${ }^{2}$ Department of Chemistry, California State Polytechnic University, Pomona, CA. \\ ${ }^{3}$ Department of Chemistry, Ferdowsi University of Mashhad, Mashhad 1436-91779, Iran.
}

\section{HIGHLIGHTS}

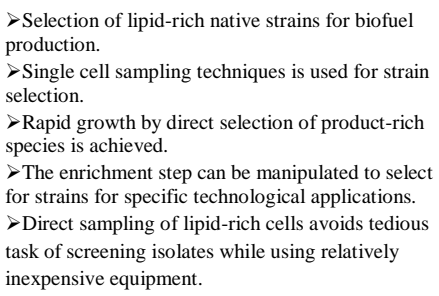

$>$ Rapid growth by direct selection of product-rich species is achieved.

$>$ The enrichment step can be manipulated to select for strains for specific technological applications. $>$ Direct sampling of lipid-rich cells avoids tedious task of screening isolates while using relatively inexpensive equipment.

\section{ARTICLE INFO}

\section{Article history:}

Received 20 September 2018

Received in revised form 12 January 2019

Accepted 12 January 2019

Available online 1 March 2019

\section{Keywords:}

Strain selection

Algae isolation

Single cell sampling

Lipid-rich microalgae

Algae screening

Biofuel production

\section{GRAPHICAL ABSTRACT}

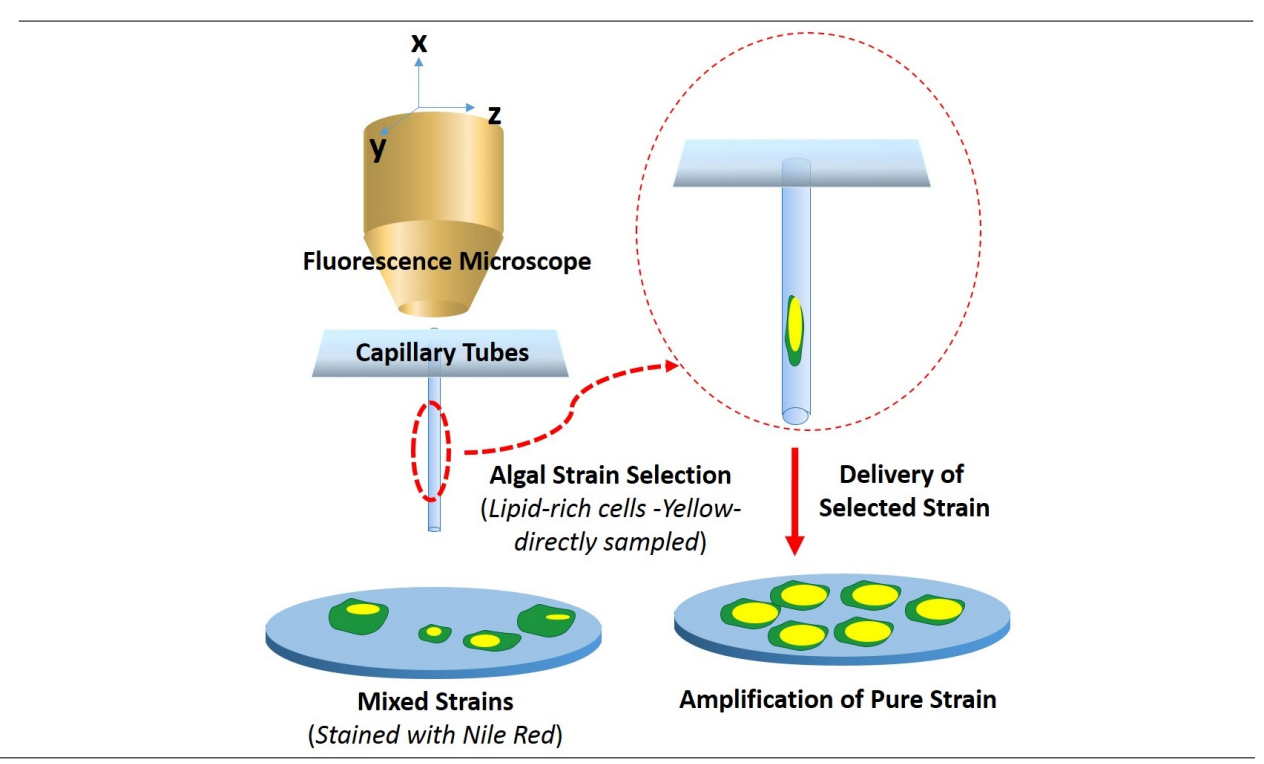

\section{ABSTRACT}

Strain selection and isolation of lipid-rich microalgae are among the most important steps for screening isolates with maximum biofuel productivity. In this work, we introduce a novel direct sampling technique that allows native strains to be selected for rapid growth under defined conditions followed by direct selection of product-rich species, two desirable characteristics of algae for mass culture. This sampling strategy directly selects the lipid-rich strains visualized under an inverted fluorescence microscope using an X-Y-Z micromanipulator. The enrichment step can be manipulated to select for strains with specific technological applications. Direct sampling of lipid-rich cells avoids the tedious task of screening isolates while using relatively inexpensive equipment.

* Corresponding author at: Tel.: +989374997785

E-mail address: $\underline{\text { h.ahmadzadeh@um.ac.ir }}$

Please cite this article as: Huang S.T., Goh J.L., Ahmadzadeh H., Murry M.A. A rapid sampling technique for isolating highly productive lipid-rich algae strains from environmental samples. Biofuel Research Journal 21 (2019) 920-926. DOI: 10.18331/BRJ2019.6.1.3 


\section{Introduction}

The quest for economically and environmentally viable alternatives to petroleum-based fuels has been the driving force behind the rapid growth of the biofuels industry. Biodiesel, an alternative to diesel fuel, is produced from oils via transesterification producing Fatty Acid Methyl Esters (FAMEs) that can be used directly as a transportation fuel. Because biodiesel is renewable, nontoxic, and biodegradable, it has the potential to replace conventional diesel fuel. However, first generation biofuels including biodiesel produced from plant oils extracted from corn, soy, and palm oil and bioethanol derived from the fermentation and distillation of traditional crops such as sugar cane and corn, have been associated with serious negative impacts. More specifically, they have hindered global food supplies (with regards to soy and corn) and have resulted in the destruction of tropical rain forest with regards to sugar cane and oil palm. In response to the difficulties associated with the first generation biofuels, algae-based biofuels have gained considerable attention in recent years. Many species of microalgae have properties well suited for commercial scale biodiesel production including rapid growth rate, high lipid content, and the ability to grow on marginal lands in saline or waste waters not suitable for agricultural irrigation (Murry and Benemann, 1980; Sheenan et al., 1998).

The extensive work carried out by the DOE/NREL sponsored Aquatic Species Program to explore large-scale algae production for biodiesel production provided a number of recommendations for further work (Sheenan et al., 1998). Key among these was to isolate native strains for mass cultivation to ensure adaptation to local conditions. We are particularly interested in native strains that grow rapidly on animal wastes to allow bioremediation and nutrient recovery from animal wastes, a serious problem in intensive meat and dairy operations. We are also interested in strains that can grow in waters high in salinity and/or alkalinity. An early, but key analysis of the economics of algaebased biofuels considered the importance of water quality and availability to the economics, design, and operation of large-scale ponds (Weissmann and Goebel, 1987). They considered low cost, high salt or alkaline waters and agricultural waste waters as prime candidates for economically feasible ponding scenarios in sunny areas where cheap land is available, notably in the southwest U.S. It has also been suggested that algae isolated from fluctuating and adverse environments, such as tide pools and estuaries, would be opportunistic fast growing strains with an ability to accumulate storage lipids as a survival mechanism (Duong et al., 2012).

Microalgae are a phylogenetically diverse group of photosynthetic microorganisms that vary greatly in their metabolic capabilities, environmental adaptations, and growth rate. Microalgae have oil content that varies from 15 to $77 \%$ of the dry weight (Chisti, 2007) and in general, lipid biosynthesis is regulated by environmental variables as recently reviewed (Lari et al., 2016). Although many culture collections of microalgae have been established, the variety of unknown strains present in the environment with potential application in the production of biofuels and for other biotechnological uses is likely very high and has been poorly explored to date. "Bio-prospecting" for useful strains requires rapid high throughput screening procedures in order to isolate novel species that are adapted to production location and for specific purposes.

Although several techniques for microalgae isolation have been described previously, including single-cell isolation using serial dilutions, micromanipulation, gravimetric separation, and atomized cell spray (Anderson et al., 2005; Mutanda et al., 2011), traditional means of isolating algal strains are time consuming and require further screening of axenic cultures to identify growth and lipid biosynthesis patterns. Flow cytometry coupled to cell sorting has led to rapid selection of lipid rich strains (Pereira et al., 2011; Cabanelas et al., 2014 and 2016) but the cost of these instruments restricts use of this technology to larger well-funded labs. To facilitate isolation of desirable strains for both rapid growth and high oil productivity, we have developed an enrichment strategy, coupled with a capillary aided sampling procedure. This allows for the direct selection of oil-rich strains from a heterogeneous population. The objective is to select individual algal cell candidates for biofuel and feed production coupled to bioremediation of agricultural wastes.

\section{Materials and Methods}

\subsection{Strains and culture conditions}

Environmental samples were collected from livestock fields and fecal contaminated marine, freshwater, and estuarine sites in Southern California (Table 1) and transferred to defined media at approximately 1:10 dilution. Conductivity was measured at sampling sites using a Beckman Coulter meter (Model pHi 410; Fullerton, CA) and samples were incubated in media with matching salinity. Enrichment cultures were incubated at $24^{\circ} \mathrm{C}$ on a rotary shaker $(100 \mathrm{rpm})$ under constant light at a photon flux density of $59 \mu \mathrm{mol} \mathrm{m} \mathrm{m}^{-2} \mathrm{~s}^{-1}$ for 4 to $7 \mathrm{~d}$ to enrich for fast growing strains.

\subsection{Enrichment media}

Basal media (B) contained $\mathrm{KH}_{2} \mathrm{PO}_{4} 7 \mathrm{mM} ; \mathrm{H}_{3} \mathrm{PO}_{4}, 3.4 \mathrm{mM} ; \mathrm{MgSO}_{4}, 0.1$ $\mathrm{mM} ; \mathrm{CaCl}_{2}, 0.07 \mathrm{mM} ; \mathrm{KCl}, 2.35 \mathrm{mM}$; FeNaEDTA, $10 \mathrm{mg} / \mathrm{L}$; and trace elements (Ripka et al., 1979). As source of nitrogen, $\mathrm{NH}_{4} \mathrm{Cl}, 5 \mathrm{mM}(\mathrm{BN})$ or filter sterilized urea, $5 \mathrm{mM}$ (BUN), was used. For an organic media with all essential elements, a duck pond sample was supplemented with $10 \%$ Luria broth (LB) and B (DP). An artificial sewage (AS) media (OECD, 2001) contained in tap water: peptone, $160 \mathrm{mg}$; meat extract, $110 \mathrm{mg}$; urea, 30 $\mathrm{mg} ; \mathrm{K}_{2} \mathrm{HPO}_{4}, 28 \mathrm{mg}$; $\mathrm{NaCl}, 7 \mathrm{mg} ; \mathrm{CaCl}_{2} .2 \mathrm{H}_{2} \mathrm{O}, 4 \mathrm{mg}$; and $\mathrm{MgSO}_{4} .7 \mathrm{H}_{2} 0,2$ mg. Artificial seawater (SW) media (containing $\mathrm{NaCl}, 0.4 \mathrm{M} ; \mathrm{MgSO}_{4}, 13.3$ $\mathrm{mM} ; \mathrm{MgCl}_{2}, 25 \mathrm{mM} ; \mathrm{CaCl}_{2}, 8.2 \mathrm{mM} ; \mathrm{KCl}, 9.4 \mathrm{mM} ; \mathrm{NH}_{4} \mathrm{Cl}$ and/or urea (filter sterilized), $5 \mathrm{mM} ; \mathrm{Na}_{2} \mathrm{CO}_{3}, 0.16 \mathrm{mM} ; \mathrm{KH}_{2} \mathrm{PO}_{4}, 0.5 \mathrm{mM}$; FeNaEDTA, $10 \mathrm{mg} / \mathrm{L}$ ), was used. All media were supplemented with $\mathrm{F} / 2$ vitamins (Guillard and Ryther, 1962), Tris pH 7.5 (10mM) to control pH, and either streptomycin, vancomycin or kanamycin at $25 \mu \mathrm{g} / \mathrm{mL}$ to decrease bacterial contamination. For solid media, agar was added at $1.5 \% \mathrm{w}: \mathrm{v}$ and dispensed into petri dishes or microtiter dishes for cell isolation. To enrich for strains with a "N-trigger" for lipid biosynthesis, actively growing mixed enrichment cultures were harvested by centrifugation $(5,000 \mathrm{rpm}, 10 \mathrm{~min})$ and the pellet washed in $\mathrm{N}$-free media, re-suspended in low nitrogen media $\left(0.5 \mathrm{mM} \mathrm{NH}_{4} \mathrm{Cl}\right)$, and incubated for 3-4 d before sampling. Axenic strains were tested for microbial contamination and for the ability to grow heterotrophically by spotting a $10-\mu \mathrm{L}$ sample on solid LB media and incubating in the dark at room temperature for $5 \mathrm{~d}$.

\subsection{Screening for growth rates and lipid content}

Axenic cultures were inoculated (10\% v:v) with log phase cultures grown in the same media and grown as described above. The light intensity was increased up to $100 \mu \mathrm{mol} / \mathrm{m}^{2}$.s after 2 to $3 \mathrm{~d}$ of incubation to avoid light limitation. Experiments were carried out either in duplicate or in most cases in triplicate. Fv/Fm, an indicator of photosynthetic efficiency (Parkhill et al., 2001), was measured in triplicate $1 \mathrm{~mL}$ aliquots transferred to an OS1p cuvette and adapted for 20 to $30 \mathrm{~min}$ in the dark before measurements were made using an OS1p-Fl Modulated Chlorophyll Fluorometer (OptiSciences, Hudson N.H.). Biomass accumulation was measured by vacuum filtration of 10 to $25 \mathrm{~mL}$ of culture using MFS mixed cellulose ester $47 \mathrm{~mm}$ diameter, $0.45 \mu \mathrm{m}$ pore size filters. The cells were washed with several volumes of distilled water and were vacuum dried at $60{ }^{\circ} \mathrm{C}$ overnight and cooled in a desiccation chamber under vacuum before weighing. Dry weight was correlated with optical density at $650 \mathrm{nM}$ in triplicate $200 \mu \mathrm{L}$ aliquots harvested daily using a Multiskan FC with incubator (Thermo Scientific) with SkanIt Software. The growth rate was calculated during logarithmic growth phase by $\mathrm{N}=\mathrm{N}_{\mathrm{o}} \mathrm{e}^{\mathrm{kt}}$ where $\mathrm{N}$ is the biomass at end of logarithmic growth and $\mathrm{N}_{\mathrm{o}}$ is the biomass at time zero $\left(\mathrm{t}_{\mathrm{o}}\right)$, the beginning of logarithmic growth phase (Fogg, 1987). From this, the mean doubling time $\mathrm{G}$ in days (the mean generation time if the cells divide into two) is as follows (Eq. 1):

$\mathrm{G}=\frac{0.301}{\mathrm{k}} \quad \mathrm{k}=\frac{\log _{\mathrm{e}} N-\log _{\mathrm{e}} \mathrm{N}_{0}}{\mathrm{t}}$

\subsection{In-vivo lipid staining}

To identify individual cells with high lipid content, mixed enrichment cultures of both N-replete and N-deficient cultures were stained with a lipophilic fluorescent dye, Nile Red. Nile red (9-(diethyl amino) benzo[a]phenoxazin-5(5H)-one, Sigma- Aldrich) was prepared at 250 
Table 1.

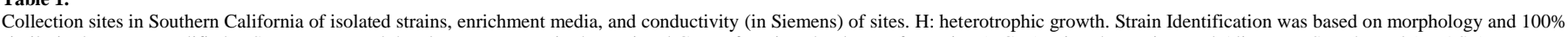
similarity between amplified ITS sequences, and the closest sequence in the National Center for Biotechnology Information (NCBI) using the Basic Local Alignment Search Tool (BLAST).

\begin{tabular}{|c|c|c|c|c|c|c|}
\hline Isolate & Species & $\begin{array}{l}\text { Gene Bank\# of related } \\
\text { spp. }\end{array}$ & $\begin{array}{c}\text { Enrichment } \\
\text { media* }\end{array}$ & Collection site ${ }^{* *}$ & $\begin{array}{l}\text { Conductivity } \\
\qquad(\mathrm{S} / \mathrm{cm})\end{array}$ & $\mathbf{H}$ \\
\hline CP214 & Auxenochlorella protothecoides & LN610701.1 & $\mathrm{BN}$ & Lyle Pond, Pomona & $880 \mathrm{uS}$ & Yes \\
\hline $\mathrm{CP} 215$ & Desmodesmus sp. & AB917110.1 & $\mathrm{BN}$ & Lyle Pond, Pomona & $880 \mathrm{uS}$ & Yes \\
\hline CPP4 & Pseudochlorella sp. & KY364701.1 & BUN & Animal lot, Pomona & - & Yes \\
\hline CPP5 & Auxenochlorella pyrenoidosa & KX752082,1 & BUN & Animal lot, Pomona & - & Yes \\
\hline CPP7 & Chlorella sorokiniana & KY303731.1 & BUN & Animal lot, Pomona & - & Yes \\
\hline CPP9 & Auxenochlorella protothecoides & LN610701.1 & BUN & Animal lot, Pomona & - & Yes \\
\hline CPP201 & Scenedesmus sp. & KU170547.1 & BUN & Lyle Pond, Pomona & $880 \mathrm{uS}$ & Yes \\
\hline CPP210 & Micractinium sp. & AB917104.1 & BUN & Lyle Pond, Pomona & $880 \mathrm{uS}$ & Yes \\
\hline CPP13 & Coelastrum sp. & GQ375097.1 & BUNQ & Animal lot, Pomona & - & Yes \\
\hline СРP98 & Chlorella vulgaris & MF686487.1 & BUNQ & Animal lot, Pomona & - & Yes \\
\hline CPP82 & Chlorella sp. & KP726221.1 & SWU & Salton Sea & $71.5 \mathrm{mS}$ & Yes \\
\hline CPP 18 & Chlorella sp. & KM061458.1 & BUNQ & Malibu Lagoon & $22.1 \mathrm{mS}$ & Yes \\
\hline CPP67 & Desmodesmus sp. & DQ417525.1 & BUNQ & Malibu Lagoon & $22.1 \mathrm{mS}$ & Yes \\
\hline CPP33 & Dictyosphaerium sp. & GQ477066.1 & BUNQ & Salton Sea & $71.5 \mathrm{mS}$ & Yes \\
\hline CPP60 & Chlorella vulgaris & MF686487.1 & BUNQ & Animal lot, Pomona & - & Yes \\
\hline СРР98 & Pseudochlorella sp. & KY364701.1 & BUNQ & Animal lot, Pomona & - & Yes \\
\hline CPP215 & Scenedesmus obliquus & FR865731.1 & BUNQ & Lagoon, San Onofre & $26.6 \mathrm{mS}$ & Yes \\
\hline CPP171 & Heterochlorella luteoviridis & LN610702 & SW & Ocean, San Onofre & $54.6 \mathrm{mS}$ & Yes \\
\hline CPP153 & Tetraselmis sp. & HE610131.1 & SW & Ocean, San Onofre & $54.6 \mathrm{mS}$ & - \\
\hline
\end{tabular}

*BN: basal media enriched with $\mathrm{NH}_{4} \mathrm{Cl}(5 \mathrm{mM})$ as nitrogen source; BUN: basal media enriched with filter sterilized urea (5 mM) as source of nitrogen; BUNQ: quarter strength BUN; SW: artificial seawater; SWU: SW enriched with filter sterilized urea $(5 \mathrm{mM})$ as source of nitrogen.

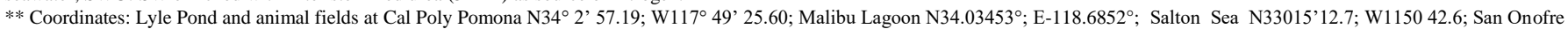
$\mathrm{N} 33^{\circ} 22^{\prime} 51.64$ : W117 $34^{\prime} 42.83$.

$\mathrm{mg} / \mathrm{L}$ in acetone and stored in darkness at $-20{ }^{\circ} \mathrm{C}$. Nile Red (NR) staining procedure was performed using $1 \mu \mathrm{g} / \mathrm{mL}$ of NR and $10 \%$ DMSO to allow cell penetration (Chen et al., 2009). Cells were incubated in the dark at $37{ }^{\circ} \mathrm{C}$ for 10 min and observed microscopically using the DAPI filter system.

For monitoring lipid content in axenic cultures, BODIPY505/515 (4, 4difluro-1, 3, 5, 7-tetramethyl-4-bora-3a, 4adiaza- s-indacene, Invitrogen Molecular Probes, Carlsbad, CA) was prepared in DMSO to give a stock solution of $5 \mathrm{mM}$ and stored in darkness at $-20^{\circ} \mathrm{C}$. An incubation time of 30 $\mathrm{min}$ at room temperature was used for all assays. The stained algae were analyzed on a Varian Cary Eclipse Fluorescence 96-well Microplate Spectrophotometer (XP900, Varian Australia Pty Lt) with a $490 \mathrm{~nm}$ narrow band $(10 \mathrm{~nm})$ excitation filter, a $525 \mathrm{~nm}$ emission filter $(10 \mathrm{~nm})$, and photomultiplier at $400 \mathrm{~V}$. Relative fluorescence intensity of stained cells was calculated by subtraction of autofluorescence of the unstained algae and correlated with gravimetric lipid measurements of each strain $\left(\mathrm{R}^{2}\right.$ of correlation ranged from 0.909 to 0.997 )

\subsection{Lipid analysis}

The lipid contents of microalgae cultures were analyzed by modifications to the gravimetric method of Bligh and Dyer (1959). Briefly, $1 \mathrm{~g}$ of wet algal biomass was mixed with $2 \mathrm{~mL}$ of methanol and $1 \mathrm{~mL}$ of chloroform and disrupted using $0.5 \mathrm{~mm}$ glass beads for $2 \mathrm{~min}$ at high speed in a mini-beadbeater (Biospec, Inc. Bartlesville, OK). The mixture was vortexed for 2 min and centrifuged at $12,000 \mathrm{rpm}$ for $10 \mathrm{~min}$. The chloroform layer was collected carefully and the extraction process was repeated three times. The organic extracts were combined and dried by $\mathrm{N}_{2}$ airflow. The lipid residues were dried in an oven at $60{ }^{\circ} \mathrm{C}$ for $50 \mathrm{~min}$ and cooled in a vacuum desiccator before weighing.

\subsection{Sampling}

An Olympus IX-71 inverted fluorescence microscope (Olympus Corporation, Tokyo, Japan) equipped with a U-MWB cube with a band pass 450-480 nm excitation filter and a dichroic mirror, DM500, with high transmission above $500 \mathrm{~nm}$, was used to view NR-stained cells. The barrier filter was a BA515, with a steep slope below $515 \mathrm{~nm}$. A clear Plexiglas capillary holder was mounted between the light condenser and the objective lens, without blocking light transmission for observations (Ahmadzadeh et al., 2004). The capillary holder was mounted on a micromanipulator (Soma Scientific, Irvine, CA) to position the capillary over cells of interest. A flexible fused silica capillary tubing $(150 \mu \mathrm{m}$ Outer Diameter (OD) and a $50 \mu \mathrm{m}$ Inner Diameter (ID) (Polymicro Technologies, Phoenix, AZ ) was held vertically by the Plexiglas holder and sampling was achieved with pressure applied by a $1 \mathrm{~mL}$ disposable syringe coupled to the tubing (Fig. 1). The capillary was sterilized by flushing with $70 \%$ ethanol and cleaned with sterile media before sampling. The sampling end of the capillary was trimmed using a sapphire cutter to obtain a clean straight cut.

To identify individual cells with high lipid content, cells were diluted to approximately $10^{5}$ cells $/ \mathrm{mL}$ and a $10 \mu \mathrm{L}$ sample was placed on a silanized coated glass cover slip and observed using bypass filters to visually identify lipid-rich cells. Using the $\mathrm{X}$ and $\mathrm{Y}$ manipulation knobs, the lumen of the capillary was positioned directly above the target cell. Using the Z manipulation knob, the micromanipulator was lowered to position the target cell within the capillary lumen. Negative pressure was applied on the opposite side of the capillary to capture the cell that was then deposited on the surface of solid media for growth and colony formation.

To determine the viability of cells stained with NR, serial dilutions of stained cells were plated on solid media in triplicates after staining and 
(A)

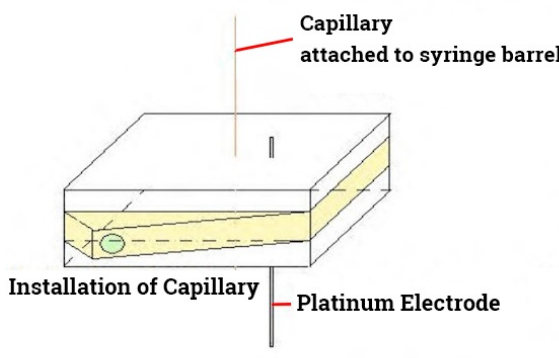

(B)

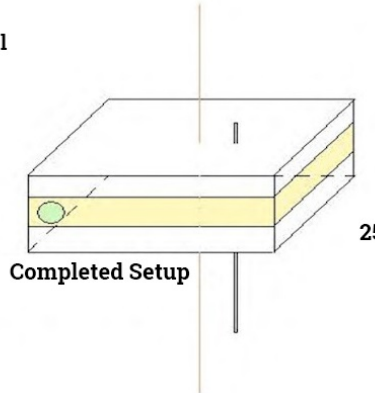

50 micron Capillary

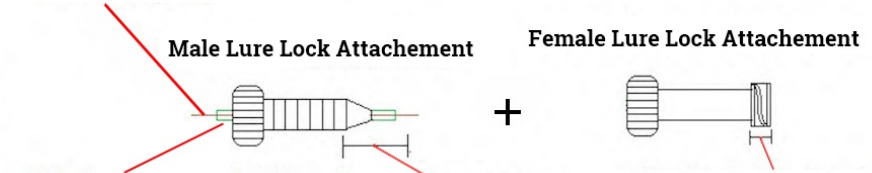

250 micron (od) Plastic Tubing Teflon Tape Wrapping

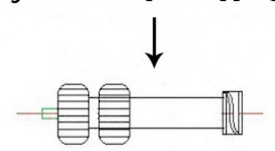

Fig. 3. A) Diagram of Plexiglas cubes assembly used to mount capillary to micromanipulator, and B) Configuration of luer lock system to hold capillary tube to syringe.

colony forming units $(\mathrm{CFU})$ were compared between treated and untreated cells. To assess the effect of exposure to fluorescent light during the sampling procedure, the percentage of cells sampled that formed viable colonies after 10 $\mathrm{d}$ of incubation in the light was measured.

\subsection{Strain identification}

Genomic DNA was extracted as described by Fawley and Fawley (2004). The ITS region ( $\sim 650 \mathrm{bp})$ from the 3 'end of the $18 \mathrm{~S}$ small subunit to the 5 'end of the 28S large subunit was amplified using ITS 4 (5, TCCTCCGCTTATTGATATGC3) and ITS 5 (5'GGAAGTAAAAGTCGT AACAAGG3) primers developed by White et al. (1990). Amplifications were done in a $50 \mu \mathrm{L}$ reaction mixture containing $5 \times$ GoTaq colorless buffer (Promega, WI), $2 \mathrm{mM} \mathrm{MgCl} 2,250 \mu \mathrm{M}$ of each dNTP, $0.1 \mu \mathrm{M}$ of each primer, 1 unit of GoTaq Taq polymerase, and $1 \mu \mathrm{L}$ of template DNA. The PCR cycle was as follows: an initial cycle of denaturation, $95^{\circ} \mathrm{C}$ for $5 \mathrm{~min}$; followed by 35 cycles of denaturation, $95^{\circ} \mathrm{C}$ for $1 \mathrm{~min}$; annealing, $55^{\circ} \mathrm{C}$ for $1 \mathrm{~min}$; and extension, $72{ }^{\circ} \mathrm{C}$ for $1 \mathrm{~min}$; and a final extension step of $72{ }^{\circ} \mathrm{C}$ for $5 \mathrm{~min}$. PCR products were visualized under UV illumination on $2 \%$ agarose gel containing ethidium bromide $(1 \mu \mathrm{g} / \mathrm{mL})$. PCR products were purified using an UltraClean PCR clean-up DNA purification kit (MO BIO, Carlsbad, CA) and were commercially sequenced in both directions (Retrogen Inc, San Diego CA). Sequence analysis, alignment, and phylogenetic trees were constructed using Geneious software (Drummond et al., 2010).

\section{Results and Discussion}

Algae strains isolated for biotechnical applications need to grow rapidly in large-scale systems to ensure an economically sustainable process. This is especially true in selecting strains for low value commodity products including biodiesel and animal feeds in which the economics of production dictates the use of outdoor ponds. Fast growing strains, well adapted to the local environment and culture media, have the potential to out compete invading competitors as well as providing high biomass productivity which also favors the economics of downstream processing (Borowitzka, 1997).

Environmental samples collected from sites in Southern California with significant fecal contamination, including marine sites, estuaries, fresh water, and animal fields (Table 1), were grown in nitrogen-rich defined media with varying combinations of salinity and nitrogen sources to amplify proportionally the fastest growing strains under specific media conditions. The strains fell within a cluster of Chlorophytes associated with eutrophic waters and most were heterotrophic. Aliquots of each culture were transferred to nitrogen-free media to identify strains in which nitrogen limitation triggers lipid biosynthesis. The mixed cultures amplified under both N-replete and $\mathrm{N}$-deplete media and stained with NR, were viewed under an Olympus IX-71 inverted fluorescence microscope to visually identify individual strains with high oil content. As seen in Figure 2, individual cells in mixed cultures show significant variations in the intensity of NR staining.

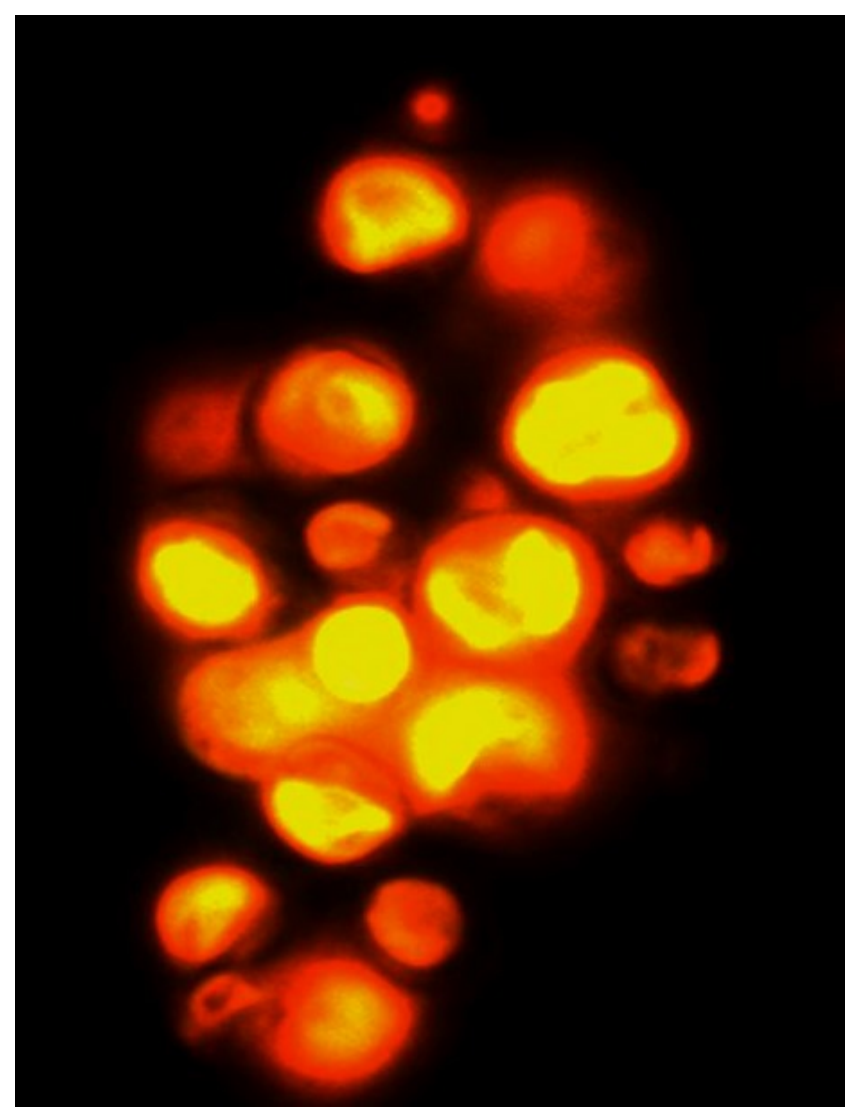

Fig. 2. Mixed culture of algae sampled from a cow pasture at Cal Poly Pomona, cultured for a week in B media supplemented with ammonia and urea and then transferred to N-media for $4 \mathrm{~d}$ before NR staining. Cells were viewed at $1000 \times$ using an Olympus IX-71 fluorescence microscope and a DAPI filter system. Lipids stain yellow while chlorophyll autofluorescence

Most of the algal strains isolated here were relatively fast-growing under $\mathrm{N}$-replete conditions due to the enrichment protocol. Growth rates were comparable to those found in the literature for similar species (Obata et al. 2009; Ong et al., 2010; Chia et al., 2013; Taziki et al., 2015). Also, the majority of the isolated strains reported herein were heterotrophic, presumably because they were isolated from sites with high organic content. Growth rates and lipid contents were variable in response to the 
Table 2

Growth rate during exponential growth, lipid content as percentage of dry weight, and Fv/Fm values of select isolates.

\begin{tabular}{|c|c|c|c|c|}
\hline Strain & Media* & Growth rate (d) & Lipid (SD) (\%) & Fv/Fm (SD) \\
\hline \multirow{4}{*}{ Auxenchlorella CPP214 } & $\mathrm{B}$ & 1.53 & $19.26(0.52)$ & $0.78(.012)$ \\
\hline & $\mathrm{B}-\mathrm{N}$ & - & $38.2(.864)$ & $0.553(.004)$ \\
\hline & BQ-N & - & $46.56(1.22)$ & $0.44(.008)$ \\
\hline & DP & 0.7 & $49.7(.534)$ & $0.778(.015)$ \\
\hline \multirow{3}{*}{ Desmodesmus CPР215 } & B & 0.657 & $15.55(.416)$ & $0.776(.026)$ \\
\hline & B-N & - & $39.53(.41)$ & $0.539(.029)$ \\
\hline & DP & 0.556 & $44.33(1.02)$ & $0.697(.06)$ \\
\hline \multirow{3}{*}{ Pseudochlorella CPP4 } & $\mathrm{B}$ & 0.66 & $21.13(.98)$ & $0.766(.02)$ \\
\hline & $\mathrm{B}-\mathrm{N}$ & - & $48.1(1.6)$ & $0.419(.025)$ \\
\hline & DP & 0.55 & $34.13(2.1)$ & $0.77(.025)$ \\
\hline \multirow{3}{*}{ Auxenochlorella CPP5 } & $\mathrm{B}$ & 0.6257 & $19.5(.408)$ & $0.776(.017)$ \\
\hline & B-N & - & $38.53(.411)$ & $0.416(.024)$ \\
\hline & DP & 0.556 & $29.55(.415)$ & $0.763(.033)$ \\
\hline \multirow{3}{*}{$\begin{array}{l}\text { Chlorella sorokiniana } \\
\text { CPP7 }\end{array}$} & B & 1.06 & $20.1(.804)$ & $0.713(.026)$ \\
\hline & $\mathrm{B}-\mathrm{N}$ & & $28.7(.496)$ & $0.506(.032)$ \\
\hline & DP & 0.726 & $35.33(1.69)$ & $0.743(.042)$ \\
\hline \multirow{3}{*}{$\begin{array}{l}\text { Auxenochlorella } \\
\text { protothecoides CPP9 }\end{array}$} & $\mathrm{B}$ & 0.633 & $20.7(.922)$ & $0.73(.032)$ \\
\hline & $\mathrm{B}-\mathrm{N}$ & - & $40.06(.82)$ & $0.402(.012)$ \\
\hline & DP & 0.553 & $36.66(1.2)$ & $0.763(.0124)$ \\
\hline \multirow{3}{*}{ Scenedesmus CPР201 } & B & 0.876 & $17.56(.41)$ & $0.76(.043)$ \\
\hline & $\mathrm{B}-\mathrm{N}$ & - & $43.53(1.22)$ & $0.38 .5(.0147)$ \\
\hline & DP & 0.62 & $46.63(.449)$ & $0.726(.032)$ \\
\hline \multirow{3}{*}{$\begin{array}{l}\text { Micractinium sp. } \\
\text { CPP210 }\end{array}$} & B & 0.97 & $17.95(.05)$ & $0.743(.03)$ \\
\hline & $\mathrm{B}-\mathrm{N}$ & - & $42.6(2.05)$ & $0.396(.036)$ \\
\hline & DP & 0.653 & $33.33(1.24)$ & $0.743(.031)$ \\
\hline \multirow{4}{*}{ Coelastrum sp.CPP13 } & B & 0.96 & $16.5(1.08)$ & $0.759(.042)$ \\
\hline & BQ & 0.648 & $20.83(.845)$ & $0.776(.017)$ \\
\hline & BQ-N & - & $45.36(.59)$ & $0.52(.022)$ \\
\hline & DPQ & 0.579 & $38.8(.216)$ & $0.752(.038)$ \\
\hline \multirow{3}{*}{$\begin{array}{l}\text { Chlorella vulgaris } \\
\text { CPP98 }\end{array}$} & BQ & 0.8 & $21.06(.82)$ & $0.683(.016)$ \\
\hline & BQ-N & - & $49.13(.837)$ & $0.496(.007)$ \\
\hline & DPQ & 0.67 & $41.33(1.24)$ & $0.736(.033)$ \\
\hline \multirow{3}{*}{ Chlorella sp. CPP82 } & SW & 0.45 & $21.73(1.26)$ & $0.757(.043)$ \\
\hline & SW-N & - & $44.23(.555)$ & $0.4026(.013)$ \\
\hline & AS & - & $44.2(1.07)$ & $0.396(.012)$ \\
\hline \multirow{4}{*}{ Chlorella sp. CPP18 } & B & 0.7 & $46.4(1.1)$ & $0.778(.019)$ \\
\hline & B-N & - & $28.7(2.4)$ & $0.416(.021)$ \\
\hline & DP & 0.556 & $51.1(.828)$ & $0.759(.043)$ \\
\hline & AS & - & $49.06(.899)$ & $0.468(.025)$ \\
\hline \multirow{4}{*}{ Desmodesmus sp.CPP67 } & BQ & 0.7 & $27.86(1.64)$ & $0.753(.046)$ \\
\hline & BQ-N & - & $41.1(.828)$ & $0.472(.0288)$ \\
\hline & DPQ & 0.656 & $45.4(1.74)$ & $0.68(.066)$ \\
\hline & AS & & $42.46(.49)$ & $0.405(.03)$ \\
\hline \multirow{3}{*}{$\begin{array}{l}\text { Dictyosphaerium } \\
\text { sp.CPP33 }\end{array}$} & BQ & 0.75 & $28.5(1.04)$ & $0.736(.028)$ \\
\hline & BQ-N & - & $40.1(.94)$ & $0.48(.024)$ \\
\hline & DPQ & 0.65 & $45.1(.94)$ & $0.616(.032)$ \\
\hline \multirow{4}{*}{$\begin{array}{l}\text { Chlorella vulgaris } \\
\text { CРP60 }\end{array}$} & BQ & 0.746 & $37.4(.864)$ & $0.736(.028)$ \\
\hline & BQ-N & - & $30.5(3.67)$ & $0.455(.03)$ \\
\hline & DPQ & 0.55 & $34.3(1.73)$ & $0.703(.012)$ \\
\hline & AS & - & $36.6(2.05)$ & $0.473(.025)$ \\
\hline \multirow{3}{*}{ Pseudochlorella CPP57 } & BQ & 0.97 & $21.33(1.69)$ & $0.7233(.036)$ \\
\hline & BQ-N & - & $46(1.63)$ & $0.398(.0082)$ \\
\hline & AS & - & $41.6(2.4)$ & $0.407(.014)$ \\
\hline & SW & 2.1 & $23.8(1.28)$ & $0.773(.018)$ \\
\hline $\begin{array}{l}\text { Scenedesmus obliquus } \\
\text { СРР215 }\end{array}$ & BQ & 0.696 & $27.66(1.69)$ & $0.763(.025)$ \\
\hline & BQ-N & - & $48.1(.94)$ & $0.452(.027)$ \\
\hline Heterochlorella & SW & 0.913 & $30.2(1.6)$ & $0.676(.017)$ \\
\hline luteoviridis CPP171 & SW-N & - & $41.33(1.24)$ & $0.409(.022)$ \\
\hline Tetraselmis spp. & SW & 0.657 & $19.55(.416)$ & $0.783(.016)$ \\
\hline CPP153 & SW-N & - & $39.8(.169)$ & $0.525(.033)$ \\
\hline
\end{tabular}

* B: basal media; B-N: nitrogen-depleted B; BQ-N: quarter strength B-N; DP: duck pond sample supplemented with $10 \%$ Luria broth (LB) and B; DPQ: quarter strength DP; SW: artificial seawater; SW-N: : nitrogen-depleted SW; AS: artificial sewage. media used for cultivation. In most cases, growth rates increased significantly when basal inorganic media was supplemented with organics (DP media) and often lipid content in log phase was enhanced over those seen in N-deplete media (Table 2). In contrast, AS media promoted early rapid growth relative to inorganic media but was followed by declining growth, Fv/Fm values, and enhanced lipid biosynthesis, similar to the response in $\mathrm{N}$-deplete cultures. Because of the high organic $\mathrm{N}$ levels in AS it is unlikely that $\mathrm{N}$ limited growth and impacted photosynthetic efficiency, but rather that other essential nutrients such as iron and trace minerals were growth limiting leading to enhanced lipid biosynthesis as described earlier (Spoehr and Milner, 1949; Shifrin and Chisholm, 1981).

To isolate oil-rich cells from a heterogeneous suspension, the field was viewed at low magnification under dim bright field illumination to focus and to roughly position the capillary, and then under $400 \times$ magnification, the cells were illuminated with fluorescence light briefly to identify cells with high lipid content. The light was returned to bright field illumination and the micromanipulator was positioned directly over the target cell (Fig 3a). Using the $\mathrm{Z}$ manipulation knob, the micromanipulator was slowly lowered to penetrate the suspension and position the target cell within the capillary lumen (Fig. 3b). A light pressure was applied to the syringe plunger to pull the cell into the lumen of the capillary tube and then displaced onto the surface of solid agar (Fig. 3c). Following capture, the agar microtiter plate was incubated in light for 7 to $10 \mathrm{~d}$ until visible colonies appeared (Fig. 3d).

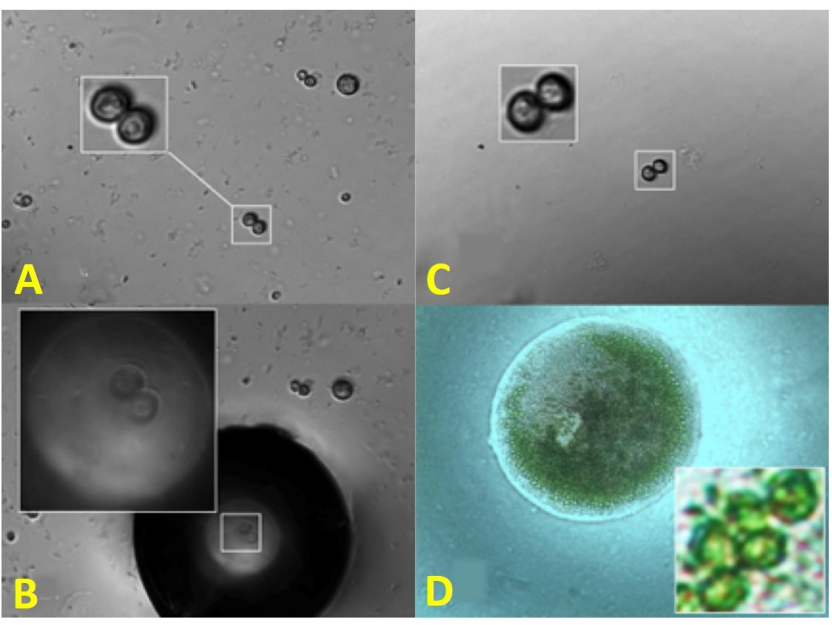

Fig. 3. A) Identification of target cells. Small inset at $400 \times$ magnification; Larger inset, same cells viewed at 1,000 $\times$ magnification; B) Small inset, view of targeted cells inside the lumen of the capillary viewed at $400 \times$ magnification; large inset, viewed at $1000 \times$ magnification C) Cells deposited on the surface of solid media, at 400 and 1,000× magnifications; and D) $10 \mathrm{~d}$ old colony from target cells $(10 \times)$ and under $1,000 \times$ magnification.

\subsection{Viability of stained cells}

The viability of cells stained with NR for 10 min in $10 \%$ DMSO was estimated using plate counts of stained cells and compared to cells stained, viewed under fluorescent light and deposited on solid media. Viability of two axenic strains, CPP 2.1.98, a freshwater strain, and CPP 2.2.27, a brackish water isolate, showed an $87 \%$ and $85.8 \%$ survival rate, respectively, compared to unstained cells. Of 178 NR-stained cells subjected to the sampling protocol (which included brief exposure to incoming blue excitation light to identify lipid-rich strains), $139(78 \%)$ survived following transfer to solid media.

\subsection{Characterization of selected isolates}

Figure 4 shows a typical growth curve of isolates cultured under both $\mathrm{N}$-replete (A) and $\mathrm{N}$-deplete (B) conditions in basal media. Light intensity 

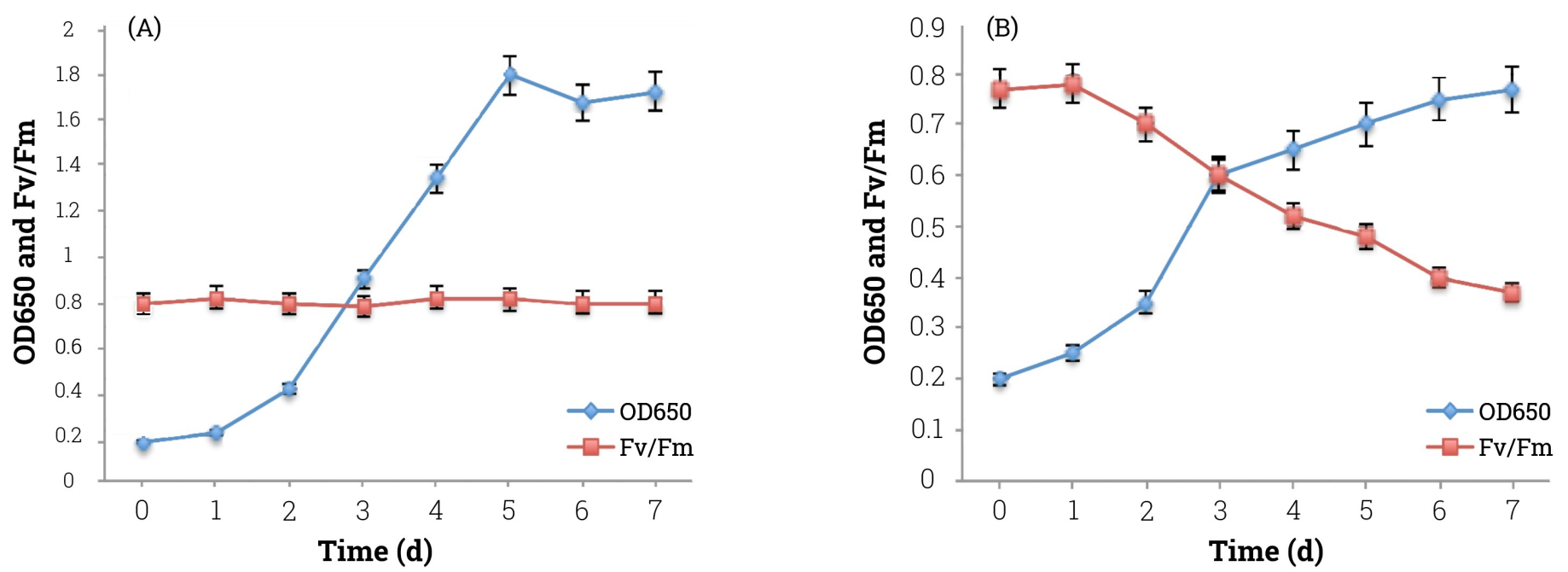

Fig. 4. Growth kinetics of Auxenchlorella sp. CPP9 grown in basal media with, A) $5 \mathrm{mM} \mathrm{NH}_{4} \mathrm{Cl}$ compared to B) growth in $0.5 \mathrm{mM} \mathrm{NH} 4 \mathrm{Cl}$.

was $55 \mu \mathrm{E} / \mathrm{m}^{2} / \mathrm{s}$ following inoculation and was raised to $100 \mu \mathrm{E} / \mathrm{m}^{2} / \mathrm{s}$ at day 2 . Cultures were inoculated with $\log$-phase cultures and by day $2, \log$ phase growth typically began but slowed at day 5 due to light limitation as indicated in experiments in which by increasing light intensity up to $150 \mu \mathrm{E} / \mathrm{m}^{2} / \mathrm{s}$ allowed for continued rapid growth beyond day 5 (data not shown). While $\mathrm{Fv} / \mathrm{Fm}$ readings hovered around 0.8 in N-replete media; by day 2, Fv/Fm values began to drop in $\mathrm{N}$-deplete cultures although growth continued to increase as indicated by absorption at $650 \mathrm{~nm}$.

Growth, Fv/Fm, and lipid content were monitored daily in promising axenic cultures, using $\mathrm{OD}_{650} \mathrm{~nm}$ to follow growth and the Bodipy assay to measure lipid content, in several media with both $\mathrm{N}$-deplete and $\mathrm{N}$-replete conditions (Table 2). The lipid content as a percent of dry weight was calculated during $\log$ phase for $\mathrm{N}$-replete cultures and at 3-5 d following rapid growth in $\mathrm{N}$ deplete media as $\mathrm{Fv} / \mathrm{Fm}$ values dropped from 0.7 to 0.8 in log phase to between 0.4 to 0.5 under $\mathrm{N}$-deplete conditions. While most strains isolated showed a significant $\mathrm{N}$-trigger to lipid accumulation under $\mathrm{N}$ deprivation, two strains (Chlorella sp. CPP18 and CPP60) had higher lipid contents in log-phase growth in the presence of $\mathrm{N}$ than in $\mathrm{N}$-deplete conditions as $\mathrm{Fv} / \mathrm{Fm}$ values dropped. Most of the strains reported here were heterotrophic (Table 1), and growth rates were variable in response to the media used for cultivation. In most cases growth rates increased significantly when basal inorganic media was supplemented with organics (DP media) and often lipid content in log phase was enhanced above that found in N-deplete media (Table 2). The AS media promoted early rapid growth relative to inorganic media but led to decreasing growth and Fv/Fm values after 4 to $5 \mathrm{~d}$ of cultivation. These cultures showed a high lipid content as was observed in $\mathrm{N}$-deplete media.

Key parameters determining the economic feasibility of algae feedstock for biofuels, feed and other applications, especially in outdoor ponds, include biomass productivity, lipid content, and lipid productivity. For bioremediation of wastewaters, active nutrient uptake is correlated with active growth. Lipid and carotenoid content tends to be induced by stress, especially nutrient limitation, preventing further growth and shunting excess photosynthate towards either triglyceride accumulation (Illman et al., 2000; Jakobsen et al., 2008; Griffiths and Harrison, 2009; Rodolfi et al., 2009; Lv et al., 2010) or carbohydrate synthesis (Chiu et al., 2017). Lipid and starch synthesis can compete for precursors to each pathway (Li et al., 2013) as demonstrated by experiments to disrupt starch synthesis in Chlamydomonas reinhardtii that lead to high levels of lipid accumulation ( $\mathrm{Li}$ et al., 2010). Biomass productivity is usually inversely correlated with overall lipid production, the product of lipid content and biomass productivity. However, high lipid productivity under $\mathrm{N}$ replete conditions was described earlier in a marine Isochrysis strain (Feng et al., 2011). Griffiths and Harrison (2009) surveyed the literature to compare growth rates and lipid content under $\mathrm{N}$-deplete and $\mathrm{N}$-replete conditions, showing a stronger correlation between biomass and lipid productivity.

Achieving high biomass productivity with high lipid content is a challenge. High productivity is also advantageous in a two-stage process, as described earlier (Lyon et al., 2015), with the first stage designed to optimize biomass production and nutrient recovery from wastewaters, and followed by a second phase to induce hyper-lipid production by nutrient limitation. For bioremediation schemes coupled to biomass production, identifying strains in which high lipid productivity occurs during nutrientreplete conditions, such as in CPP 18 and CPP 60, is of interest.

\section{Conclusions}

This method allows native strains to be selected for rapid growth under defined conditions followed by direct selection of product-rich species, two desirable characteristics of algae for mass culture. The enrichment step can be manipulated to select for strains for specific technological applications. Direct sampling of lipid-rich cells avoids the tedious task of screening isolates while using relatively inexpensive equipment.

\section{Acknowledgements}

This project was jointly supported by USDA Grant \# 11332837 and California State University Agriculture Research Institute (ARI) system grant \#15-01-107

\section{References}

[1] Ahmadzadeh, H., Johnson, R.D., Thompson, L., Arriaga, E.A., 2004. Direct sampling from muscle cross sections for electrophoretic analysis of individual mitochondria. Anal. Chem. 76(2), 315-321.

[2] Anderson, R.A., Kawachi, M., 2005. Traditional microalgae isolation techniques, in: Anderson, R.A. (ed.), Algal culturing techniques. Elsevier, Amsterdam, pp. 83-100.

[3] Bligh, E.G., Dyer, W.J., 1959. A rapid method for total lipic extraction and purification. Can. J. Biochem. Physiol. 37(8), 911 917.

[4] Borowitzka, M.A., 1997. Microalgae for aquaculture: opportunities and constraints. J. Appl. Phycol. 9, 393.

[5] Cabanelas, I.T.D., van der Zwart, M., Kleinegris, D.M.M., Barbosa, M.J., Wijffels, R.H., 2015. Rapid method to screen and sort lipid accumulating microalgae. Bioresour. Technol. 184, 47-52.

[6] Cabanelas, I.T.D., van der Zwart, M., Kleinegris, D.M., Wijffels, R.H., Barbosa, M.J., 2016. Sorting cells of the microalga 
Chlorococcum littorale with increased triacylglycerol productivity. Biotechnol. Biofuels. 9(1), 183.

[7] Chen, W., Zhang, C.W., Song, L.R., Sommerfeld, M., Hu, Q., 2009. A high throughput Nile red method for quantitative measurement of neutral lipids in microalgae. J. Microbiol. Meth. 77(1), 41-47.

[8] Chia, M.A., Lombardi, A.T., Melão, M.D.G.G., 2013. Growth and biochemical composition of Chlorella vulgaris in different growth media. Anais da Academia Brasileira de Ciências. 85(4), 1427-1438.

[9] Chisti, Y., 2007. Biodiesel from microalgae. Biotechnol. Adv. 25, 294306.

[10] Collyer, D.M., Fogg, G.E., 1955. Studies on fat accumulation by algae. J. Exp. Bot. 6(17), 256-275.

[11] Duong, V.T., Li, Y., Nowak, E., Schenk, P.M., 2012. Microalgae isolation and selection for prospective biodiesel production. Energies. $5(6), 1835-1849$

[12] Fawley, K.P., Fawley, M.W., 2007. Observations on the diversity and ecology of freshwater Nannochloropsis (Eustigmatophyceae), with descriptions of new taxa. Protist. 158(3), 325-336.

[13] Feng, D., Chen, Z., Xue, S., Zhang, W., 2011. Increased lipid production of the marine oleaginous microalgae Isochrysis zhangjiangensis (Chrysophyta) by nitrogen supplement. Bioresour. Technol. 102(12), 6710-6716.

[14] Fogg, G.E., Thake, B., 1987. Algal cultures and phytoplankton ecology. The University of Wisconsin Press.

[15] Griffiths, M.J., Harrison, S.T., 2009. Harrison. Lipid productivity as a key characteristic for choosing algal species for biodiesel production. J. Appl. Phycol. 21(5), 493-507.

[16] Guillard, R.R., Ryther, J.H., 1962. Studies of marine planktonic diatoms: I. Cyclotella nana Hustedt and Detonula confervacea (Cleve) Gran. Can. J. Microbiol. 8(2), 229-239.

[17] Ho, S.H., Shimada, R., Ren, N.Q., Ozawa, T., 2017. Rapid in vivo lipid/carbohydrate quantification of single microalgal cell by Raman spectral imaging to reveal salinity-induced starch-to-lipid shift. Biotechnol. Biofuels. 10(1), 9 .

[18] Illman, A.M., Scragg, A.H., Shales, S.W., 2000. Increase in Chlorella strains calorific values when grown in low nitrogen medium. Enzyme Microb. Technol. 27(8), 631-635.

[19] Jakobsen, A.N., Aasen, I.M., Josefsen, K.D., Strom, A.R., 2008. Accumulation of docosahexaenoic acid-rich lipid in thraustochytrid Aurantiochytrium sp strain T66: effects of $\mathrm{N}$ and $\mathrm{P}$ starvation and $\mathrm{O}_{2}$ limitation. Appl. Microbiol. Biotechnol. 80(2), 297-306.

[20] Lari, Z., Moradi-kheibari, N., Ahmadzadeh, H., Abrishamchi, P., Moheimani, N.R, Murry, M.A., 2016. Bioprocess engineering of microalgae to optimize lipid production through nutrient management. J. Appl. Phycol. 28(6), 3235-3250

[21] Li, Y., Han, D., Hu, G., Sommerfeld, M., Hu, Q., 2010. Inhibition of starch synthesis results in overproduction of lipids in Chlamydomonas reinhardtii. Biotechnol. Bioeng. 107(2), 258-268.

[22] Li, Y., Han, D., Yoon, K., Zhu, S., Sommerfeld, M., Hu, Q., 2013. Molecular and cellular mechanisms for lipid synthesis and accumulation in microalgae: biotechnological implications, Second ed, in: Richmond, A., Hu, Q. (Eds.), Handbook of Microalgal Culture. Appl. Phycol. Biotechnol. John Wiley \& Sons, Ltd, Oxford, UK.

[23] Lyon, S.R., Ahmadzadeh, H., Murry, M.A., 2015. Algae-based wastewater treatment for biofuel production: processes, species, and extraction methods, in: Moheimani, N., McHenry, M., de Boer, K., Bahri, P. (Eds.), Biomass and Biofuels from Microalgae. Biofuel and Biorefinery Technologies, Springer, Cham. 95-115.
[24] Lv, J.M., Cheng, L.H., Xu, X.H., Zhang, L., Chen, H.L., 2010 Enhanced lipid production of Chlorella vulgaris by adjustment of cultivation conditions. Bioresour. Technol. 101(17), 6797-6804.

[25] Murry, M.A., Benemann, J.R., 1980. Fresh and brackish water aquatic plant resources, in: Zaborsky, O. (Ed.), Handbook of Biosolar resources, vol II. CRC Press, Boca Raton. 407-470

[26] Mutanda, T., Ramesh, D., Karthikeyan, S., Kumari, S., Anandraj, A., Bux, F., 2011. Bioprospecting for hyper-lipid producing microalgal strains for sustainable biofuel production. Bioresour. Technol. 102(1), 57-70

[27] OECD, 2001. Test No. 303: simulation test-aerobic sewage treatment--A: activated sludge units; B: biofilms. OECD Publishing, Paris.

[28] Obata, M., Toda, T., Taguchi, S., 2009. Using chlorophyll fluorescence to monitor yields of microalgal production. J. Appl. Phycol. 21(3), 315-319.

[29] Ong, S., Kao, C.Y., Chiu, S.Y., Tsai, M.T., Lin, C.S., 2010. Characterization of the thermal-tolerant mutants of Chlorella sp. with high growth rate and application in outdoor photobioreactor cultivation. Bioresour. Technol. 101(8), 2880-2883

[30] Parkhill, J.P., Maillet, G., Cullen, J.J., 2001. Fluorescence-based maximum quantum yield for PSII as a diagnosis of nutrient stress. J. Phycol. 37(4), 517-529.

[31] Pereira, H., Barreira, L., Mozes, A., Florindo, C., Polo, C., Duarte C.V., Custódio, L., Varela, J., 2011. Microplate-based high throughput screening procedure for the isolation of lipid-rich marine microalgae. Biotechnol. Biofuels. 4(1), 61.

[32] Rippka, R., Deruelles, J. Waterbury, J.B., Herdman, M., Stanier R.Y., 1979. Generic assignments, strain histories and properties of pure cultures of cyanobacteria. Microbiology. 111(1), 1-61.

[33] Rodolfi, L., Chini Zittelli, G., Bassi, N., Padovani, G., Biondi, N., Bonini, G., Tredici, M.R., 2008. Microalgae for oil: strain selection, induction of lipid synthesis and outdoor mass cultivation in a lowcost photobioreactor. Biotechnol. Bioeng. 102(1), 100-112.

[34] Roessler, P.G., 1990. Environmental control of glycerolipid metabolism in microalgae: commercial implications and future research directions. J. Phycol. 26(3), 393-399.

[35] Sheehan, J., Dunahay, T., Benemann, J.R., Roessler, P., 1998. A look back at the U.S. department of energy's aquatic species program: biodiesel from algae. National Renewable Energy Lab. NREL/TP-580-24190.

[36] Shifrin, N.S., Chisholm, S.W., 1981. Phytoplankton lipids: interspecific differences and effects of nitrate, silicate and lightdark cycles. J. Phycol. 17(4), 374-384.

[37] Spoehr, H.A., Milner, H.W., 1949. The chemical composition of Chlorella; effect of environmental conditions. Plant physiol. 24(1), 120-149.

[38] Takia, M., Ahmadzadeh, H., Murry, M.A., 2015. Growth of Chlorella vulgaris in high concentrations of nitrate and nitrite for wastewater treatment. Current Biotechnol. 4(4), 441-447.

[39] Taziki, M., Ahmadzadeh, H., Murry, M.A., Lyon, S.R., 2015 Nitrate and nitrite removal from wastewater using algae. Curr. Biotechnol. 4(3), 426-440.

[40] Weissman, J.C., Goebel, R.P., 1987. Factors affecting the photosynthetic yield of microalgae. FY 1986 Aquatic Species Program Annual Report. Solar Energy Research Institute. Golden, Colorado, SERI/SP-231-3071, 139-168. 